\title{
Literasi Etika Pergaulan Remaja melalui Karya Fiksi bagi Siswa-Siswi di TBM Kolong, Ciputat
}

\author{
Ria Antika ${ }^{1}$, Puri Bakthawar ${ }^{2}$, Aisyah Al-Baroroh ${ }^{3}$, Prihatin Pujiastuti ${ }^{4}$ \\ Universitas Pamulang ${ }^{1234}$ \\ Korespondensi: dosen01053@unpam.ac.id ${ }^{1}$, dosen02416@unpam.ac.id², \\ dosen01054@unpam.ac.id ${ }^{3}$,dosen01119@unpam.ac.id ${ }^{4}$
}

\begin{abstract}
Community service or Pengabdian kepada Masyarakat (PkM) is an activity conducted by academic community in order to answer the demand of society's needs. Based on observation to activity of TBM (Public Reading Community) Kolong Ciputat located in Ciputat Street, South Tangerang, the PkM group initiates to conduct an activity that has an impact to children and students as the loyal visitors of TBM Kolong, especially about the importance of social ethics in life. There are some problems happened related to ethical issue of teenagers. If these matters are not immediately solved, it is feared that they will become major problems for the nation in the future. The solution offered in this PkM activity is by conducting a literacy activity in TBM Kolong Ciputat as the PkM partner. The literacy activity will focus on reading literary works narrating some ethical values such as integrity, religiosity, mutual cooperation, and independence.
\end{abstract}

Keywords: literacy, ethics, fiction, social service

\begin{abstract}
Abstrak
Kegiatan pelayanan kepada mayarakat merupakan kegiatan penerapan ilmu dalam memenuhi tuntutan dinamika perkembangan dan kemajuan di berbagai aspek kehidupan mayarakat yang dilakukan oleh civitas akademika. Berdasarkan observasi terhadap aktivitas Taman Bacaan Masyarakat di bawah jembatan Ciputat yang berada di jalan Ciputat, Tangerang Selatan, kelompok PkM kami melakukan sebuah kegiatan yang memiliki dampak bagi anak-anak yang menjadi pengunjung setia taman bacaan tersebut tentang pentingnya pemahaman dan peningkatan etika pergaulan dalam kehidupan sehari-hari. Permasalahan-permasalahan seputar minimnya etika pergaulan di kalangan remaja kerap terjadi di masyarakat. Hal-hal tersebut apabila tidak segera ditangani dikhawatirkan akan menjadi masalah besar terhadap karakter bangsa di masa depan. Solusi yang ditawarkan dalam kegiatan PKM untuk aspek pendidikan anak-anak pengunjung TBM Ciputat adalah dengan melalui kegiatan literasi mengingat bahwa hal tersebut juga sejalan dengan bidang keilmuan Fakultas Sastra, Program Studi Sastra Inggris. Literasi menjadi basis utama program PkM kali ini, yang disesuaikan dengan etika pergaulan pada kelompok usia remaja (SMP).
\end{abstract}

Kata kunci: literasi, etika, fiksi, pengabdian 


\section{A. Pendahuluan}

Taman Bacaan Masyarakat (TBM) Kolong Jembatan Ciputat terletak di Jalan Ciputat, Tangerang Selatan. Lokasi ini berada tepat di bawah kolong flyover Ciputat, bersebelahan dengan pasar tradisional Ciputat. Lokasinya yang berada di antara jalan raya membuatnya unik dan tidak biasa. Tidak seperti taman bacaan pada umumnya, di tempat ini tidak berlaku aturan "harap tenang". Meskipun lokasinya selalu bising karena suara kendaraan berlalu-lalang. TBM Kolong tetap diminati oleh banyak pengunjung khususnya anak-anak.

Kawasan kolong jembatan tadinya adalah tempat pangkalan ojek, sopir angkot, dan tempat beristirahat bagi pengunjung yang kelelahan. Sebelum menjadi taman bacaan, tempat ini berbau dan kumuh karena dipenuhi oleh sampah. Dalam menyikapi masalah tersebut, pemerintah daerah setempat membangun taman bacaan untuk masyarakat yang dapat dinikmati oleh siapa saja yang membutuhkan. Tempat ini menjadi rapi, bersih, dan terawat karena dikelola dengan baik. Pengelola TBM bekerjasama dengan relawan dari universitas-universitas sekitar Ciputat untuk mengelola TBM tersebut. Tujuan awal dari TBM Kolong adalah agar anak-anak para pedagang atau masyarakat setempat dapat mendapatkan tambahan pendidikan atau ilmu yang berguna dan agar mereka terhindar dari pengaruh negatif dari lingkungan yang kurang kondusif.

Para pengunjung TBM Kolong mayoritas adalah anak-anak yang berasal dari sekolah yang sama maupun berbeda. Rentang usia mereka rata-rata adalah usia sekolah taman kanak-kanak hingga sekolah menengah pertama. Namun, ada juga anak-anak usia belum sekolah karena mereka ingin ikut kakak atau saudara mereka. Mereka berbaur menjadi satu untuk belajar dan bermain bersama. Diantara puluhan pengunjung yang mayoritas adalah anak-anak, pada PkM kali ini terdapat tujuh orang remaja usia SMP. Menurut salah satu pengurus TBM, jumlah mereka memang selalu berubah di setiap tahunnya.

Seiring dengan perkembangan zaman, berbagai permasalahan acap muncul, terutama pada kelompok usia remaja. Jika melihat pada berbagai fenomena yang terpotret di media massa, berbagai masalah acap kali muncul seperti perilaku tawuran antar remaja, perundungan atau bullying, kurangnya toleransi beragama, dan lain-lain. Secara lebih detail, berikut adalah permasalahan-permasalahan yang seringkali terjadi:

a. Adanya tawuran antar remaja. Tidak hanya terjadi antar sekolah berbeda, namun tawuran juga kerap terjadi antar remaja dalam sekolah yang sama;

b. Kurangnya toleransi beragama. Contohnya adalah penghinaan terhadap agama tertentu yang terjadi di lingkungan sekolah maupun di sosial media dan adanya diskriminasi dalam pergaulan terhadap penganut agama lain yang berbeda dengan kelompoknya;

c. Terjadinya perundungan dan kekerasan, baik secara fisik, verbal, social, maupun cyber;

d. Memaksakan kehendak kepada oranglain;

e. Mengotori dan merusak lingkungan;

f. Kurangnya rasa peduli dan menghargai penyandang disabilitas; 
Hal-hal di atas adalah contoh permasalahan karena kurangnya pemahaman tentang etika pergaulan di kalangan remaja yang seringkali terjadi. Hal tersebut dapat semakin buruk apabila tidak ada upaya penanganan yang dilakukan. Mengingat kemajuan teknologi dan internet semakin pesat, hal-hal buruk tersebut semakin banyak terjadi tidak hanya dalam kehidupan nyata sehari-hari tetapi juga dalam kehidupan maya melalui media sosial.

Dengan demikian, solusi yang ditawarkan dalam kegiatan PkM kali ini adalah mengenai penguatan etika pergaulan remaja yang akan dilakukan melalui kegiatan literasi. Kirsch \& Jungeblut dalam buku Literacy: Profile of America's Young Adult mengartikan literasi sebagai kemampuan seseorang dalam menggunakan informasi untuk mengembangkan pengetahuan sehingga mendatangkan manfaat bagi masyarakat (via Irianto dan Febrianti, 2017). Dalam hal ini, literasi dapat digunakan sebagai penguat etika pergaulan remaja yang tertuang dalam beberapa cerita pendek yang memiliki berbagai pelajaran dan pesan positif di dalamnya.

Di sisi lain, pendidikan karakter khususnya tentang pemahaman dan penguatan etika pergaulan dirasa sangat penting untuk ditanamkan kepada para generasi muda, dalam hal ini kepada anak-anak TBM Kolong Ciputat usia remaja. Hal tersebut berlandaskan pada salah satu program prioritas Presiden Joko Widodo (Jokowi) dan Wakil Presiden Jusuf Kalla yang diimplimentasikan oleh Kementerian Pendidikan dan Kebudayaan melalui gerakan Penguatan Pendidikan Karakter (PPK) yang digulirkan sejak tahun 2016. Tujuan dasar dari pendidikan karakter adalah untuk revolusi karakter bangsa melalui generasi muda demi kehidupan masa depan bangsa yang terus Berjaya.

Di dalam pendidikan karakter tersebut, terdapat lima nilai karakter utama yang bersumber dari Pancasila, yang kemudian menjadi prioritas pengembangan gerakan PPK. Nilai-nilai karakter tersebut yaitu religius, nasionalisme, integritas, kemandirian, dan kegotongroyongan. Masing-masing nilai saling berinteraksi satu sama lain, berkembang secara dinamis, dan membentuk keutuhan pribadi.

Nilai karakter religius mencerminkan keberimanan terhadap Tuhan yang Maha Esa yang diwujudkan dalam perilaku melaksanakan ajaran agama dan kepercayaan yang dianut, menghargai perbedaan agama, menjunjung tinggi sikap toleran terhadap pelaksanaan ibadah agama dan kepercayaan lain, hidup rukun dan damai dengan pemeluk agama lain.

Nilai karakter nasionalis merupakan cara berpikir, bersikap, dan berbuat yang menunjukkan kesetiaan, kepedulian, dan penghargaan yang tinggi terhadap bahasa, lingkungan fisik, sosial, budaya, ekonomi, dan politik bangsa, menempatkan kepentingan bangsa dan negara di atas kepentingan diri dan kelompoknya.

Nilai karakter integritas merupakan nilai yang mendasari perilaku yang didasarkan pada upaya menjadikan dirinya sebagai orang yang selalu dapat dipercaya dalam perkataan, tindakan, dan pekerjaan, memiliki komitmen dan kesetiaan pada nilai-nilai kemanusiaan dan moral.

Nilai karakter mandiri merupakan sikap dan perilaku tidak bergantung pada orang lain dan mempergunakan segala tenaga, pikiran, waktu untuk merealisasikan harapan, mimpi dan cita-cita. Siswa yang mandiri memiliki etos kerja yang baik, 
tangguh, berdaya juang, profesional, kreatif, keberanian, dan menjadi pembelajar sepanjang hayat.

Nilai karakter gotong royong mencerminkan tindakan menghargai semangat kerja sama dan bahu membahu menyelesaikan persoalan bersama, menjalin komunikasi dan persahabatan, memberi bantuan/pertolongan pada orang-orang yang membutuhkan.

Memperhatikan situasi di atas, perlu dilakukan beberapa langkah untuk mencapai perubahan-perubahan di masa yang akan datang. Fakultas Sastra Unpam yang telah bekerjasama dengan TBM Kolong pada kesempatan ini mengirimkan tim pelaksana kerjasama untuk melakukan kegiatan PkM yang diharapkan mampu memberikan kontribusi terhadap penguatan etika pergaulan di kalangan remaja dengan melakukan penyuluhan melalui karya fiksi naratif pada kaum remaja di TBM Kolong Ciputat.

Luaran yang diharapkan dalam kegiatan PkM Mini ialah buku saku untuk siswa-siswi TBM Kolong dengan tema etika pergaulan di kalangan remaja. Buku saku ini secara garis besar akan berisikan materi-materi mengenai etika pergaulan remaja, khususnya kelompok usia SMP, mengenai apa saja yang boleh dilakukan dan tidak boleh dilakukan, bagaimana cara menghormati teman serta lawan jenis, bagaimana menciptakan hubungan sosial yang baik, dan sebagainya. Buku saku ini juga akan dilengkapi dengan cerita fiksi naratif ciptaan dosen dan mahasiswa, yang menampilkan pesan-pesan moral sehingga diharapkan pembacanya mampu mengambil nilai-nilai positif dari cerita fiksi tersebut. Melalui pembuatan buku saku yang kemudian akan dibagikan kepada mitra PkM, diharapkan semangat dari kegiatan literasi dapat terwujudkan melalui kegiatan PkM kali ini.

\section{B. Pelaksanaan dan Metode}

Berdasarkan paparan di atas, dapat dilihat bahwa literasi kemudian menjadi basis utama kegiatan PkM kali ini, sebagai solusi permasalahan untuk penguatan etika pergaulan remaja di kalangan siswa-siswi kelompok umur SMP di TBM Kolong Ciputat. Oleh karena itu, kegiatan PkM akan diarahkan pada aktivitas-aktivitas berbasis literasi. Dalam konteks ini, kegiatan literasi yang akan dilaksanakan akan berbasis pada literasi kesusastraan. Penggunaan teks-teks karya sastra atau fiksi naratif dirasa tepat karena karya sastra dapat menjadi sarana pembelajaran yang menyenangkan, efektif, dan tidak membebani mitra PkM. Melalui karya sastra atau fiksi naratif, mitra PkM dapat menikmati cerita sekaligus menarik nilai-nilai serta pesan positif yang dikandung dalam karya sastra, dalam hal ini berkenaan dengan nilanilai serta etika pergaulan di kalangan remaja dalam konteks era digital atau informatika.

Sasaran program kegiatan ini adalah anak-anak dari sekolah tingkat SMP yang merupakan siswa binaan Taman Bacaan Masyarakat (TBM) Kolong Jembatan Ciputat, Tangerang Selatan.

Adapun pelaksanaan kegiatan Pengabdian kepada Masyarakat oleh beberapa dosen dan mahasiswa Program Studi Sastra Inggris Universitas Pamulang di TMB 
Kolong Jembatan, Ciputat, Tangerang Selatan, dengan tabel kegiatan sebagai tabel berikut:

\begin{tabular}{|l|l|l|}
\hline No & \multicolumn{1}{|c|}{ Kegiatan } & \multicolumn{1}{|c|}{$\begin{array}{c}\text { Waktu } \\
\text { Pelaksanaan }\end{array}$} \\
\hline 1 & $\begin{array}{l}\text { Diskusi pelaksaan Pengabdian kepada Masyarakat } \\
\text { dengan staff penanggung jawab mitra }\end{array}$ & 5 September 2020 \\
\hline 2 & $\begin{array}{l}\text { Pengajuan proposal Pengabdian kepada } \\
\text { Masyarakat }\end{array}$ & 19 November 2020 \\
\hline 3 & Persiapan materi Pengabdian kepada Masyarakat & $\begin{array}{l}\text { 20- 30 November } \\
\text { 2020 }\end{array}$ \\
\hline 4 & Pelaksanaan Pengabdian kepada Masyarakat & $\begin{array}{l}\text { 1-31 Desember } \\
\text { 2020 }\end{array}$ \\
\hline 5 & $\begin{array}{l}\text { Pembuatan laporan Pengabdian kepada } \\
\text { Masyarakat }\end{array}$ & 2-10 Januari 2020 \\
\hline 6 & $\begin{array}{l}\text { Pelaporan hasil kegiatan Pengabdian kepada } \\
\text { Masyarakat }\end{array}$ & 15 Januari 2020 \\
\hline
\end{tabular}

Dikarenakan situasi wabah pandemi COVID-19 yang melanda di hampir seluruh negara di dunia termasuk Indonesia, maka proses pembelajaran pada kegiatan Pengabdian kepada Masyarakat yang biasanya dilakukan secara tatap muka diubah menjadi pembelajaran secara daring. Untuk itu proses pembuatan buku saku dengan judul buku, "AWESOME WITH INTEGRITY, MUTUAL COOPERATION, INDEPENDENCE, AND RELIGIOUSITY" dilaksanakan dengan tahapan sebagai berikut:

\begin{tabular}{|l|l|}
\hline \multicolumn{1}{|c|}{ TANGGAL } & \multicolumn{1}{c|}{ URAIAN KEGIATAN } \\
\hline 15 September 2020 & $\begin{array}{l}\text { Briefing mengenai teknik pelaksanan PKM dengan } \\
\text { mahasiswa }\end{array}$ \\
\hline 5 Oktober 2020 & Persiapan PKM untuk penyusunan buku saku \\
\hline 15 Oktober 2020 & $\begin{array}{l}\text { Rapat perumusan Konsep penentuan materi (Zoom Meeting } \\
\text { dan Whatsapp Group) }\end{array}$ \\
\hline 1 November 2020 & Pemilihan dan penetapan materi \\
\hline 5 November 2020 & Diskusi dan pemilihan cerita \\
\hline 15 November 2020 & Pengumpulan sumber referensi \\
\hline 2 Desember 2020 & Penyusunan isi buku saku bab 1 \\
\hline 10 Desember 2020 & Penyusunan isi buku saku bab 2 \\
\hline 17 Desember 2020 & Penyusunan isi buku saku bab 3 \\
\hline 24 Desember 2020 & Penyusunan isi buku saku bab 4 \\
\hline 1 Januari 2020 & $\begin{array}{l}\text { Penyusunan cover dan daftar isi } \\
\text { Edit content dan penyelarasan akhir }\end{array}$ \\
\hline 10 Januari 2020 & Pencetakan \\
\hline 15 Januari 2020 & $\begin{array}{l}\text { Pendistribusian/ penyerahan buku saku ke TBM Kolong } \\
\text { Ciputat }\end{array}$ \\
\hline
\end{tabular}


Agar proses pembuatan buku saku dapat berjalan dengan efektif, grup PkM yang terdiri dari dosen dan mahasiswa Sastra Inggris Unpam ini dibagi menjadi empat kelompok kecil. Masing-masing kelompok terdiri dari satu dosen sebagai koordinator dan dua mahasiswa sebagai anggota. Masing-masing kelompok kecil ini bertugas melakukan penyusunan buku dengan bab atau topik yang telah ditentukan. Materi dalam buku saku disusun dalam Bahasa Inggris dan difokuskan pada pemilihan cerita atau kosa kata ringan dan sehari-hari. Buku saku ini tidak dilengkapi dengan terjemahan Bahasa Indonesia agar siswa-siswi TBM Kolong dapat berusaha mencari dan memahami kosakata dalam cerita dengan cara mereka masing-masing. Selain itu, di dalam bab buku saku juga terdapat tugas untuk mencari dan mencocokkan makna kata-kata dalam bacaan.

Melalui kegiatan ini diharapkan peserta $\mathrm{PkM}$ memahami bagaimana membentengi dari perbuataan negatif yang dapat meningkatkan kualitas diri dan kepribadian dengan menerapkan nilai nilai yang baik diri seperti nilai kejujuran, kerjasama, kemandirian, dan religius dalam kehidupan dan pergaulan sehari hari.

\section{Hasil dan Pembahasan}

Pada bagian ini akan dipaparkan mengenai hasil dan pembahasan terhadap kegiatan PkM yang telah dilakukan. Sebelum dilaksanakan kegiatan Pengabdian Kepada Masyarakat di TBM Kolong, Ciputat, para anggota PkM telah berdiskusi dengan koordinator yang menjadi perpanjangan tangan dengan pihak mitra mengenai permasalahan-permasalahan yang dimiliki oleh pihak mitra. Diskusi tersebut kemudian membuahkan hasil berupa keputusan bahwa kelompok ini berfokus pada peserta didik remaja (SMP sederajat) untuk menumbuhkan pendidikan karakter para peserta didik. Setelah membincangkan secara lebih terperinci, maka ada empat nilai karakter yang ingin ditanamkan kepada pesertra didik; religius (religiousity), integritas (integrity), gotong royong (mutual cooperation), dan kemandirian (independence/autonomy).

Di awal perencanaan, pengabdian ini merancang penyampaian kegiatan pengabdian berupa kegiatan storytelling, namun karena pandemi Covid-19 yang ternyata masih memyebabkan semua kegiatan di pihak mitra ditiadakan, maka mereka meminta para pengabdi untuk mentransformasi pengabdian yang direncanakan berupa penyuluhan, menjadi pembuatan buku saku.

Maka, tim PkM yang terdiri dari empat dosen dan delapan mahasiswa berkolaborasi untuk membuat buku saku setebal 78 halaman. Buku saku ini kemudian diperbanyak dan diberikan kepada pihak mitra sebagai pengganti bentuk penyuluhan.

Pada bagian sebelumnya disebutkan bahwa nilai karakter religius merupakan wujud keimanan kepada Tuhan yang Maha Esa yang diwujudkan dalam perilakuperilaku terpuji seperti melaksanakan ajaran agama yang dianut, menghargai perbedaan agama, dan saling bertoleransi dalam beragama. Di buku saku, nilai karakter religius coba ditanamkan melalui fiksi naratif berjudul "A Girl of A Fight".

Karya ini mengisahkan seorang remaja perempuan bernama Dianne (17), yang pulang sendirian di kegelapan malam melalui gang yang sepi. Gang itu gelap dan sepi, 
namun ia dengan berani memilih jalan tersebut agar lebih cepat sampai di rumahnya. Sayangnya, di pertengahan jalan, ia melihat seorang lelaki di ujung jalan. Ia pun mulai merasa gelisah dan memutuskan untuk berdoa, memohon kepada Tuhan agar dilindungi dari bahaya. Ia kembali melanjutkan perjalanan dan melewati lelaki itu tanpa diganggu sama sekali dan sampai di rumah dengan selamat. Keesokan harinya ia membaca koran dan mengetahui adanya peristiwa pemerkosaan seorang gadis muda yang lewat di jalan yang sama dua puluh menit setelah ia lewat. Ia merasa sangat bersyukur karena Tuhan mengabulkan doanya. Ia pun kemudian pergi ke kantor polisi untuk mencoba memberikan kesaksian. Setelah pelakunya tertangkap (lelaki yang ia lewati di ujung jalan), polisi bertanya mengapa tidak mengganggu Dianne padahal ia lewat lebih dulu daripada korban. Si pelaku pun menjawab, "Karena ia berjalan berdua dengan seorang lelaki bertubuh tinggi besar. Saya kira lelaki itu adalah ayahnya." Jawaban Si pelaku menunjukan bahwa doa yang dipanjatkan oleh Dianne telah membuatnya terlindung dari bahaya. Selain pencantuman kisah religius, di bagian tersebut juga menyuguhkan beberapa latihan untuk memperdalam pemahaman peserta didik.

Nilai karakter kedua yang dibahas di buku saku ini adalah integritas. Nilai ini ditanamkan dengan materi singkat mengenai integritas dan bagaimana remaja memupuk rasa integritas di dalam dirinya. Kemudian diikuti dengan pencantuman kisah inspiratif berjudul "The Emperor's Seed: A Story About Integrity".

Cerita itu mengisahkan seorang kaisar yang mencari seseorang untuk menjadi penerus tahtanya. Suatu hari, ia mengumpulkan ribuan anak dari seberang kerajaannya dan memberi mereka masing-masing sebuah bibit untuk ditanam di sebuah pot dan membawanya kembali ke kerajaan satu tahun setelahnya. Di antara ribuan anak itu, ada seorang anak laki-laki bernama Ling yang dibantu ibunya untuk menanam dan merawat bibit tersebut. Ia menyiram dan merawat bibit itu setiap hari. Setiap minggu, anak-anak tersebut berkumpul dan membandingkan perkembangan pertumbuhan bibit yang mereka tanam. Setelah beberapa minggu, semua benih sudah mulai tumbuh kecuali bibit milik Ling yang sama sekali tidak menunjukan tandatanda kehidupan. Setelah beberapa bulan tanaman anak lain mulai tumbuh menjadi pohon, namun bibit milik Ling masih tidak menunjukan tanda pertumbuhan. Namun, ia tetap menyirami bibit itu setiap hari. Hari yang ditentukan pun tiba. Ling sempat ragu dan ketakutan ketika hendak menuju ke kerajaan. Ia takut dihukum karena bibit yang ia tanam tidak tumbuh sama sekali. Dengan dorongan ibunya, Ling akhirnya tetap membawa pot nya. Namun sungguh mengejutkan. Ternyata Kaisar justru memilih Ling sebagai penerus tahtanya. Kemudian Sang Kaisar mengumumkan bahwa bibit yang ia berikan setahun yang lalu adalah bibit yang sudah direbus sehingga tidak mungkin dapat tumbuh. Fakta tersebut menunjukan bahwa Ling adalah satu-satunya yang menanam dan membawa kembali bibit yang diberikan oleh Kaisar.

Nilai karakter ketiga yang dibahas adalah mandiri. Nilai tersebut dipaparkan melalui materi singkat tentang mandiri beserta beberapa jenis kemandirian. Selain itu ada pula kisah inspiratif beserta latihan yang diberikan untuk menanamkan nilai kemandirian kepada peserta didik. Fiksi naratif yang ditanamkan di bagian ini berjudul "The Scholarship Jacket". 
Cerita ini mengisahkan seorang remaja berusia 14 tahun yang menginginkan sebuah jaket beasiswa. Jaket tersebut hanya diberikan kepada siswa/i terbaik selama 8 tahun berturut-turut. Martha, namanya, yakin sekali bahwa ia akan mendapatkan jaket tersebut karena ia selalu mendapatkan nilai sempurna dalam 8 tahun itu. Namun, karena ada perubahan kebijakan sekolah, jaket beasiswa yang biasanya diberikan secara cuma-cuma kepada siswa/i terbaik, mulai tahun ini dikenakan biaya. Kepala sekolah memintanya menyampaikan kepada kakeknya untuk membayarnya keesokan hari atau jaket tersebut akan diberikan kepada siswa terbaik di urutan setelahnya. Martha merasa sangat sedih karena kakek-neneknya hanyalah petani di pinggiran kota. Namun yang lebih membuat ia kecewa yaitu karena ia harus membayar sejumlah uang untuk sesuatu yang harusnya ia dapatkan sebagai reward dari kerja kerasnya selama beberapa tahun.

Setelah berbincang dengan kakeknya, kakek berkata bahwa jika itu adalah penghargaan, maka tidak seharusnya ia membayar untuk mendapatkannya. Ia menolak membayarkan jaket tersebut. Dengan perasaan hancur Martha menangis di kamarnya. Ia kesal karena Kakek tidak memberikan uang untuk membayar jaket tersebut, namun ia juga sadar bahwa kakeknya benar. Akhirnya ia memutuskan untuk menyampaikan pesan kakeknya kepada Kepala Sekolah dan mengabaikan kemungkinan bahwa ia akan kehilangan kesempatan untuk mendapatan jaket idamannya. Ia juga berkata bahwa silakan saja jika temannya yang akan menerima jaket tersebut. Namun, merasa tertampar oleh jawaban Martha, kepala sekolah akhirnya memutuskan untuk memberikan jaket itu secara cuma-cuma sebagaimana seharusnya. Martha bisa saja tidak mendengarkan perkataan kakeknya dan memilih untuk melakukan hal apapun agar dapat membayar jaket yang ia inginkan, namun ia memilih untuk mendengarkan perkataan kakeknya karena ia sadar bahwa kakeknya benar. Kemampuan meyakini dan memutuskan sesuatu yang benar dan salah merupakan salah satu tanda bahwa seseorang adalah pribadi yang mandiri.

Nilai karakter gotong royong merupakan nilai terakhir yang ditanamkan di dalam buku saku ini. Di buku saku ini selain penyuguhan materi singkat mengenai gotong-royong, disediakan pula kisah inspiratif berjudul "The Little Forest by The Tree".

Cerita ini mengisahkan sebuah desa di tepi laut di balik tebing yang mempunyai kebiasaan turun temurun untuk menanam pohon sejak mereka kecil di wilayah yang telah ditentukan. Hal ini diwajibkan karena di setiap malam tiba ada sekelompok makhluk yang menebang pohon dan merusak lingkungan sekitar tempat tinggal mereka. Namun, banyak pohon yang tidak tumbuh di beberapa area karena berbagai hal. Ada pula keluarga yang meninggal tanpa memiliki keturunan dan akhirnya tidak dapat meneruskan tradisi ini. Perlahan-lahan, jumlah pohon yang tumbuh semakin sedikit dan kondisi semakin buruk sehingga mereka terpaksa harus bermigrasi. Namun seorang pemuda menolak dan menyampaikan bahwa ia akan mempertahankan dan menumbuhkan kembali pohon-pohon di desa tersebut. Ia berniat menanam dimana pun ada lahan yang perlu ditanam tanpa menghiraukan batas-batas area yang telah lama ditetapkan. Banyak penduduk desa yang akhirnya membantunya dan akhirnya bersama-sama mereka berhasil menumbuhkan kembali pepohonan di desa itu. 
Melalui empat judul karya fiksi naratif yang telah dipilihkan, peserta didik diharapkan dapat mempelajari keempat nilai yang diharapkan. Selain melalui cerita fiksi naratif, buku saku juga dilengkapi oleh berbagai jenis latihan yang diharapkan mampu menambah pengalaman siswa TBM Kolong dalam pembelajaran Bahasa Inggris dengan cara yang menyenangkan.

Beberapa model latihan yang disusun dalam buku saku ini adalah sebagai berikut:

a. Multiple Choice Question:

Model latihan dalam multiple choice question ini berguna untuk mengukur tingkat pemahaman siswa TBM dalam memahami cerita naratif yang telah disajikan sebelumnya.

b. Match the Words:

Model latihan match the words berfungsi untuk memperkaya penguasaan kosakata bagi siswa TBM. Dalam latihan ini, siswa TBM mencocokkan vocabulary dengan artinya.

c. Writing Exercise:

Model latihan writing exercise diharapkan dapat melatih siswa TBM dalam menulis. Setelah membaca cerita naratif yang disajikan, siswa mendapat tugas untuk menuliskan cerita secara mandiri sesuai dengan imajinasi dan kreativitas masing-masing. Latihan ini dapat melatih Teknik menulis bagi siswa TBM, melatih ketelitian gramatikal, serta menumbuhkan kreativitas bagi siswa TBM.

d. Match the Images:

Model latihan match the images mirip dengan latihan match the words seperti telah dijelaskan di atas. Meskipun demikian, dalam latihan match the images, siswa TBM dilatih untuk memilih gambar yang mengilustrasikan suatu situasi. Model Latihan match the images juga dirasa tepat untuk mengasah pemahaman dan perbendaharaan kata Bahasa Inggris.

e. True or False Question:

Dalam model latihan True or False Question, siswa TBM dilatih untuk menentukan apakah statement yang dituliskan tepat atau tidak tepat sesuai dengan konteks cerita naratif yang disajikan. Latihan ini juga dirasa tepat untuk mengasah pemahaman siswa terhadap teks-teks Bahasa Inggris yang telah dibaca.

Menurut mitra PkM yaitu TBM Kolong Ciputat, pembuatan buku saku yang dikhususkan untuk siswa-siswi usia SMP ini sangat menarik. Beberapa cerita pendek yang disesuaikan dengan topik bab dan juga disertai dengan beberapa aktifitas di dalamnya membuat para siswa tertarik dan bersemangat untuk membacanya dan mengerjakan beberapa aktifitas tersebut. Selain itu, beberapa unsur gambar berwarna di dalam buku saku juga membuat kegiatan membaca cerita menjadi semakin menyenangkan. Setelah membaca keseluruhan buku saku yang terbagi ke dalam empat bab, para siswa dapat mengambil poin penting sehubungan dengan empat pilar penting dalam pengembangan pendidikan karakter, yaitu religius (religiousity), 
integritas (integrity), gotong royong (mutual cooperation), dan kemandirian (independence/autonomy).

\section{Penutup}

\section{Simpulan}

Pengabdian kepada masyarakat yang sudah dilakukan oleh Dosen dan mahasiswa Prodi Sastra Inggris, Fakultas Sastra, Universitas Pamulang di TBM Kolong, Ciputat, dengan menggunakan sistem jarak jauh/daring berupa pembuatan buku saku untuk menambah koleksi perpustakaan di TBM Kolong. Kegiatan ini telah berhasil dilaksanakan dengan baik. Pengabdian ini diharapkan memberikan kontribusi yang baik untuk pembelajaran bahasa Inggris terutama untuk pemahaman pembaca mengenai nilai-nilai dalam pergaulan remaja, serta implementasinya. Pembuatan buku saku ini juga diharapkan dapat meningkatkan minat baca peserta didik mitra.

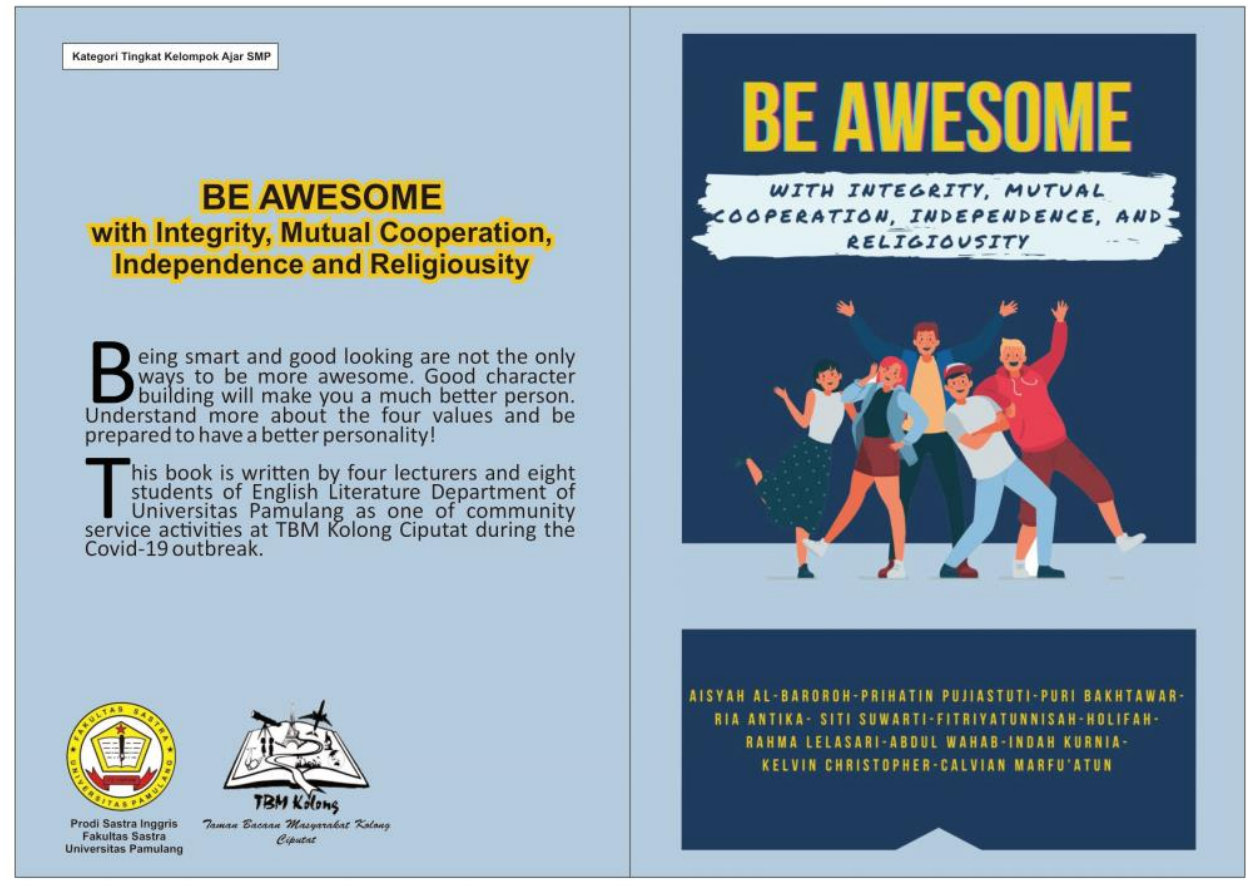

\section{Cover Buku Saku}

\section{Saran}

Kegiatan pengabdian ini diharapkan dapat berkontribusi terhadap peningkatan kemampuan membaca, Dengan membaca maka akan terbuka wawasan tentang pengetahuan dan informasi, menguatkan serta mendapatkan manfaat dari pemahaman isi dan konten dari yang telah dibaca. Membaca juga dapat menanamkan nilai-nilai tentang religius, integritas, kemadirian dan gotong royong. Harapannya nilai-nilai tersebut dapat tertanam lebih kuat di kalangan remaja yang membaca buku saku yang telah dibuat. 
Dengan perkembangan teknologi yang seakan menjadikan jarak dan waktu bukan suatu masalah bagi terselenggaranya sebuah kerja sama, serta terselenggaranya proses pentransferan ilmu dan wawasan, diharapkan bahwa pembelajaran ini tidak menjadi penghambat terjadinya proses belajar mengajar. Selain itu, dengan kemajuan teknologi yang semakin pesat diharapkan semua pihak dapat memanfaatkannya untuk kepentingan pendidikan dan pengajaran serta menjadi media untuk terus menjalin kerja sama sehingga bisa mendatangkan manfaat yang lebih baik.

\section{DAFTAR PUSTAKA}

Arifah. L. (2009). Implementasi pendidikan imtaq di smp negeri 2 bantul. [Unpublished master's thesis]. Universitas Negeri Yogyakarta.

Iriantara, Y. (2009). Literasi media: Apa, mengapa, dan bagaimana. Simbiosa Rekatama Media.

Irianto, P. O., \& Febriyanti, L. Y. (2017). Pentingnya penguasaan literasi bagi generasi muda dalam menghadapi mea. Proceeding of The 1st Education and Language International Conference. Center for International Language Development of Unissula.

Kemendikbud. (2020, November 11). Tingkat literasi remaja di indonesia masih rendah. https://www.tribunnews.com/nasional/2020/09/08/kemendikbudtingkat-literasi-remaja-di-indonesia-masih-rendah.

Keraf, G. (1985). Argumentasi dan narasi. PT. Gramedia.

Kern, R. (2000). Literacy and language teaching. Oxford University Press.

Khaerana, A., \& Nurhidayah, N. (2018). The effectiveness of story telling and story reading methods in teaching speaking. Eternal (English, Teaching, Learning, and Research Journal), 4(2). http://journal.uinalauddin.ac.id/index.php/Eternal/article/view/6209

Kirsch, I. S., \& Jungeblut, A. (1986). Literacy: Profiles of america's young adults. US' National Assessment of Educational Progress.

Luxemburg, J. V. (1989). Pengantar ilmu sastra. PT Gramedia.

Mariah. (2007). Improving students' speaking ability through story telling. [Unpublished master's thesis]. Universitas Negeri Makassar.

Nurgiatoro, B. (2005). Teori pengkajian fiksi. Gajah Mada University Press.

Oxford Learner's Dictionaries. (n.d.) Oxford learners' dictionary.com dictionary. Retrieved in December 18, 2020, from https://www.oxfordlearnersdictionaries.com

Pellowski, A. (1990). The world of storytelling. H.W. Wilson Co.

Richards, J. C. (2013). Interchange fifth edition. Cambridge University Press.

Saomah, A. (n.d.). Implikasi teori belajar terhadap pendidikan literasi. http://file.upi.edu/Direktori/FIP/JUR._PSIKOLOGI_PEND_DAN_BIMBING AN/196103171987032-

AAS_SAOMAH/IMPLEMENTASI_TEORI_BELAJAR_DALAM_PENDIDI KAN_LITERASI.pdf.

Steinberg, L. (2002). Adolescence: Sixth edition. Mc. Grawhill Companies, inc https://arbaswedan.id/memaknai-nilai-kejujuran-dalam-kehidupan/9 
Literasi Etika Pergaulan Remaja melalui Karya Fiksi

(2010). Kerangka acuan pendidikan karakter tahun anggaran 2010. Kemendiknas.

Thontowi.

A. (2005).

Hakekat

relegiusitas.

http://sumsel.kemenag.go.id/file/dokumen/hakekatreligiusitas.pdf.

Wells, B. (1987). Apprenticeship in Literacy. Interchange, 18(1/2), 109-123. https://www.academia.edu/5877768/Apprenticeship_in_literacy 